\title{
Antisipasi Efek Pandemi Covid-19 Terhadap Perekonomian Keluarga Melalui Pelatihan Pembuatan Sabun Di Desa Dalu Sepuluh B Tanjung Morawa Deli Serdang
}

\author{
Marini Damanik ${ }^{1)}$, Moondra Zubir ${ }^{2)}$, Ricky Andi Syahputra $\left.{ }^{3 *}\right)$, Rini Selly), \\ Siti Rahmah ${ }^{5)}$, Serimawarni ${ }^{6}$ ) \\ Universitas Negeri Medan $1,2,3,4,5,6)$ \\ corresponding author : rickyandi@gmail.com
}

\begin{abstract}
ABSTRAK
Dalu Sepuluh B merupakan salah satu desa yang terletak di Kecamatan Tanjung Morawa, Kabupaten Deli Serdang Sumatera Utara Indonesia. Kondisi tanah yang subur dimanfaatkan warga untuk menanam berbagai tanaman hias maupun tanaman obat di halaman rumah. Tanaman seperti lidah buaya, jeruk nipis, jeruk purut maupun sereh wangi dapat ditingkatkan nilai jualnya yaitu dengan menjadikannya produk sabun. Sabun cuci piring menjadi produk yang menjanjikan untuk meningkatkan perekonomian warga masyarakat Desa Dalu Sepuluh B. Apalagi pada masa pandemi covid-19 banyak warga yang bekerja di pabrik dirumahkan, sehingga butuh alternatif lain untuk menambah penghasilan keluarga. Adapun metode kegiatan yang dilakukan yaitu memberikan pemahaman kepada ibu pkk tentang pengembangan sabun cair cuci piring menggunakan bahan alami dan praktik pembuatan sabun cair cuci piring menggunakan bahan alami. Ibu PKK memiliki antusias yang cukup tinggi dalam melakukan kegiatan ini. Hal ini terlihat dari semangat dalam memproduksi sabun cuci piring dan setelah kegiatan pelatihan ini, ibu PKK masih memproduksi sabun cuci piring dirumah mereka untuk digunakan sendiri.
\end{abstract}

Kata kunci: Covid-19, Perekonomian Keluarga, Tanaman Obat, Sabun Cuci Piring.

\section{ABSTRACT}

Dalu Sepuluh B is one of the villages located in Tanjung Morawa Subdistrict, Deli Serdang Regency, North Sumatra Indonesia. The fertile soil conditions are used by the residents to plant various ornamental and medicinal plants in the yard. Plants such as aloe vera, lime, kaffir lime, and fragrant lemongrass can be increased their selling value by making soap products. Dish soap is a promising product to improve the economy of the residents of Dalu Sepuluh B Village. Especially during the Covid-19 pandemic, many residents who worked in factories were sent home, so they needed other alternatives to increase family income. The method of activities carried out is to provide understanding to the colleagues about the development of dishwashing liquid soap using natural ingredients and the practice of making dishwashing liquid soap using natural ingredients. PKK mothers have high enthusiasm for carrying out this activity. This can be seen from their enthusiasm in producing dish soap and after this training, PKK mothers still produce dish soap in their homes for their use.

Keywords: Covid-19, Family Economy, Medicinal Plants, Dish Soap. 


\section{PENDAHULUAN}

Sabun merupakan bahan pembersih yang digunakan dalam kehidupan sehari-hari. Bahan dasar pembuatan sabun adalah asam lemak dan garam alkali yang dibuat melalui reaksi saponifikasi. Beberapa zat adiktif dapat ditambahkan dalam proses pembuatan sabun untuk menambah nilai jual sabun, seperti zat antiseptik maupun pewangi. Sabun ada yang berbentuk padat dan ada yang cair. Sabun padat dibuat menggunakan natrium hidroksida sedangkan sabun cair menggunakan kalium hidroksida. Sabun cuci piring yang umumnya digunakan masyarakat adalah sabun cair. Sehingga, pembuatan sabun cair cuci piring memberikan peluang peningkatan kegiatan ekonomi kreatif bagi warga masyarakat Desa Dalu Sepuluh B. Sedangkan sabun mandi yang digunakan masyarakat kebanyakan adalah sabun mandi yang berbentuk padatan. Adapun hasil tanaman yang ada didaerah ini dapat dilihat pada Gambar 1.

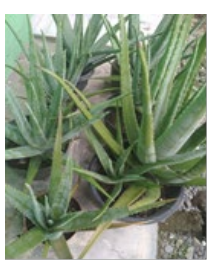

a

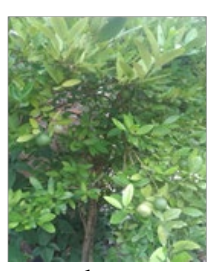

b

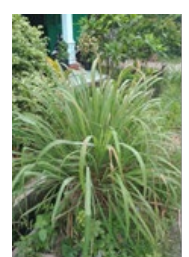

C

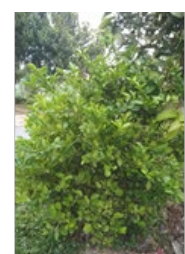

d
Gambar 1.1 Tanaman (a) Lidah Buaya, (b) Jeruk Nipis, (c) Sereh Wangi, dan (d) Jeruk Purut Milik Warga Desa Dalu Sepuluh B.

Desa Dalu Sepuluh B memiliki tanah yang subur, sehingga masyarakat desa menanam berbagai tanaman di halaman rumah mereka, baik tanaman hias maupun tanaman obat. Berdasarkan observasi yang dilakukan, beberapa tanaman dapat digunakan sebagai bahan adiktif untuk meningkatkan kualitas produk sabun, sehingga memiliki nilai jual yang lebih tinggi. Tanaman tersebut diantaranya adalah lidah buaya, jeruk nipis, jeruk purut, dan serai wangi. Kandungan yang terdapat pada lidah buaya memberikan efek antibiotik, antiseptik dan antibakteri. Sedangkan jeruk nipis mengandung banyak vitamin $\mathrm{C}$ yang sangat bermanfaat bagi peremajaan kulit, selain itu juga mengandung antibakteri dan dapat menghilangkan bau amis. Daun jeruk purut dan sereh juga mengandung antibakteri, antijamur dan antiacne sehingga dapat digunakan untuk 
menghilangkan jerawat. Sereh juga memberikan efek rileks pada tubuh. Sehingga pemanfaatan bahan-bahan alami ini sebagai zat adiktif pembuatan sabun menjadi penting.

Mitra kegiatan ini adalah PKK Desa Dalu Sepuluh B yaitu sebuah organisasi pemberdayaan perempuan yang mayoritas adalah ibu-ibu rumah tangga golongan menengah ke bawah dengan usia produktif. Programprogram PKK selain yang berkaitan dengan kesehatan seperti posyandu, keagamaan seperti perwiritan dan pengajian. Program prioritas lainnya dicanangkan mengarah kepada ekonomi kreatif untuk menambah penghasilan khususnya untuk anggota PKK dan warga masyarakat pada umumnya. Berbagai pelatihan ketrampilan telah dilakukan diantaranya pelatihan merias pengantin, pembuatan tas, tempat tissue, dan bunga dari bahan akrilik, pembuatan hantaran pernikahan, pembuatan papan bunga, ketrampilan memasak berbagai jenis kue dan pembuatan minyak herbal. Berdasarkan pelatihan-pelatihan yang telah dilakukan, tidak semua dilanjutkan sebagai sumber penghasilan mengingat mahalnya bahan baku dan biaya produksi serta minat pasar yang rendah akibat banyaknya produk serupa yang lebih murah.

PKK Desa Dalu Sepuluh B belum pernah mendapatkan informasi maupun pelatihan terkait pemanfaatan tanaman lidah buaya, sereh wangi, jeruk purut maupun jeruk nipis serta tanaman obat lainnya sebagai bahan tambahan pembuatan sabun. Mengingat sabun adalah produk yang setiap hari digunakan oleh masyarakat umum, maka memberikan peluang bisnis yang sangat menjanjikan terutama bagi anggota PKK yang semuanya adalah ibu rumah tangga. Biasanya ibu rumah tangga menambah penghasilan dengan pekerjaan musiman seperti berjualan gorengan saat ramadhan tiba, memproduksi emping melinjo saat musim melinjo dan menjadi buruh tani saat musim menanam padi tiba. Adapun pekerjaan musiman warga Desa Dalu Sepuluh-B ini adalah sebagai berikut pada Gambar 2. 

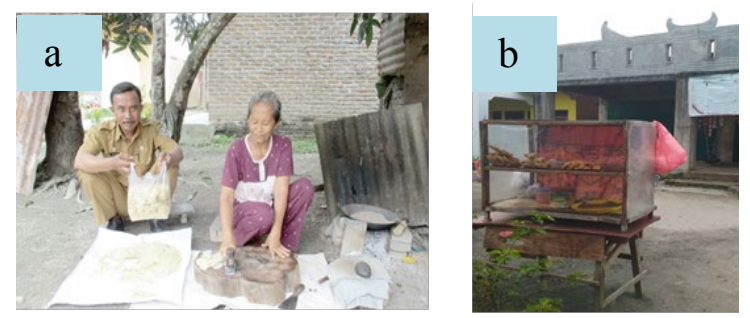

Gambar 2. Pekerjaan Musiman Warga Desa Dalu Sepuluh-B (a) Produksi Emping Melinjo, (b) Jualan Gorengan di Bulan Ramadhan

\section{METODE PELAKSANAAN}

Berdasarkan permasalahan yang telah dikemukakan maka pendekatan pendekatan sosialisasi dan metode pelatihan serta praktek langsung. Tahapan-tahapan yang dilakukan dalam kegiatan ini antara lain sebagai berikut: (1) pemaparan materi tentang peluang bisnis ekonomi kreatif bagi industri rumahan dengan memanfaatkan bahan alami (tanaman lidah buaya, jeruk nipis, jeruk purut, jarak dan sereh) milik warga masyarakat, (2) pemaparan teori dan praktek pembuatan dua jenis sabun yaitu sabun cair cuci piring dan sabun mandi kesehatan, pemaparan proses pengemasan dan desain produk sabun cair agar siap dipasarkan,

(4) pemaparan manajemen industri rumah tangga, (5) analisis dan evaluasi produk serta kegiatan pelatihan dan menarik kesimpulan.

\section{HASIL DAN PEMBAHASAN}

Kegiatan PKM ini berlangsung dengan baik dengan tahapan yang pertama yaitu dengan melakukan observasi dan pembuatan MoA dengan mitra. Kegiatan ini dilakukan dengan pendekatan sosialisasi dan metode pelatihan. Kegiatan ini meliputi beberapa tahapan-tahapan yang dilakukan dengan melihat permasalahan yang ada dimana para ibu PKK belum maksimal hasil tanaman diperkarangan rumah yang ada secara maksimal. Upaya yang dilakukan adalah memberikan pelatihan bagaimana cara pembuatan sabun cuci piring dan sabun padat melalui lima tahapan: (1) pemaparan materi tentang peluang bisnis ekonomi kreatif bagi industri rumahan dengan memanfaatkan bahan alami (tanaman lidah buaya, jeruk nipis, jeruk purut, jarak dan sereh) milik warga masyarakat, (2) pemaparan teori dan praktek pembuatan dua jenis sabun yaitu sabun cair cuci piring dan sabun mandi kesehatan, (3) pemaparan proses pengemasan dan desain produk sabun cair agar siap dipasarkan, (4) pemaparan manajemen industri rumah tangga, (5) analisis dan evaluasi 
produk serta kegiatan pelatihan dan menarik kesimpulan. Dengan diberikannya pengetahuan dan pemahaman dalam pembuatan sabun akan menjadi bekal bagi para warga untuk pengembangan yang lebih maksimal. Berikut ini pemaparan materi kepada mitra yang dapat dilihat pada Gambar 3.

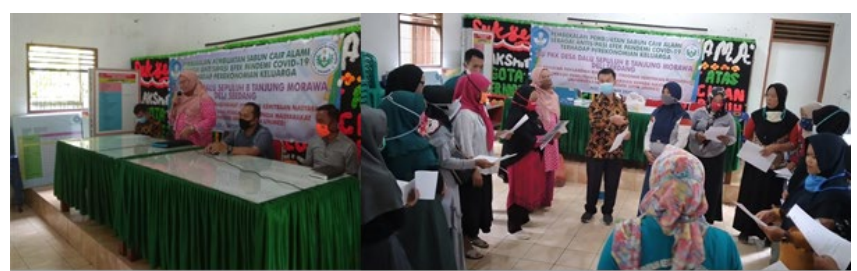

Gambar 3. Pemaparan Instruktur Antisipasi Perekonomian di masa pademi dan pembuatan sabun

Setelah memberikan bahan paparan selanjutnya diberikan pemahaman tentang proses pembuatan sabun dan langsung mempraktekkan dalam pembuatan sabun tersebut. Adapun kegiatan pembuatan sabun dapat dilihat pada Gambar 4. dan hasil sabun tersebut dapat dilihat pada Gambar 5.

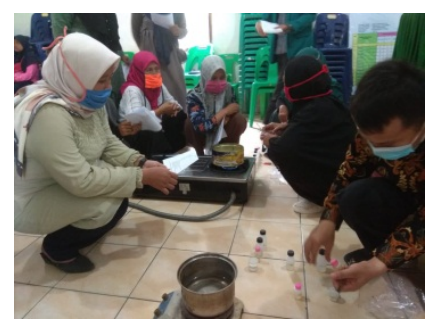

a

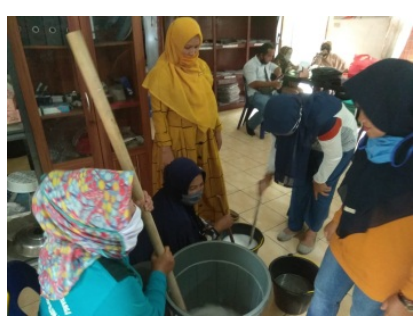

b
Gambar 4. (a) Pembuatan sabun Transparan dan pembuatan sabun cair.

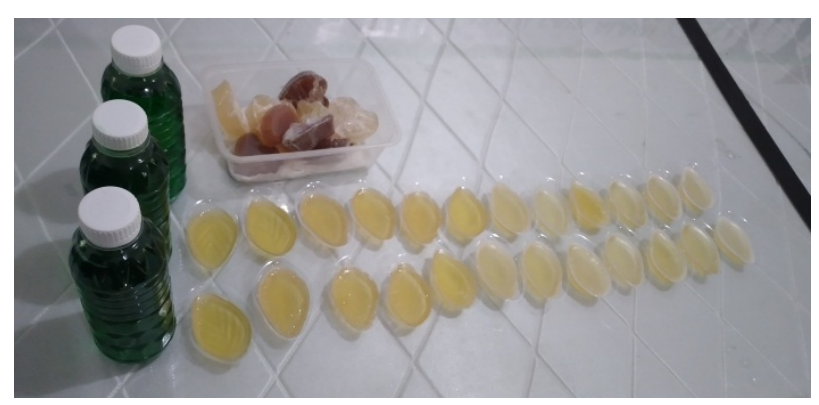

Gambar 5. Produk sabun yang dihasilkan.

Tahapan selanjutnya dari proses pelaksanaan kegiatan pada Pengabdian Kegiatan masyarakat di Desa Dalu Sepuluh B tahun 2020 yaitu seluruh peserta diarahkan untuk membuat sabun di rumah masingmasing dari bahan pelatihan yang telah dilakukan selanjutnya dilakukan pendampingan mulai dari pembeliahan bahan sabun hingga pembuatan sabun. Pendampingan dilakukan dengan bertemu langsung dan juga dengan komunikasi melalui telepon seluler. Hal ini dilakukan karena keterbatasan kondisi yang dimasa pandemi Covid 
19 jika harus dikumpulkan kembali tiap minggunya.

\section{KESIMPULAN}

Berdasarkan kegiatan pengabdian kepada masyarakat yang telah dilaksanakan di Kecamatan Tanjung Morawa ini menghasilkan peningkatan pemahaman tentang bagaimana cara memanfaatkan tanaman obat yang ada disekitar lingkungan masyarakat di Desa Dalu Sepuluh B Kecamatan Tanjung morawa. Selain itu juga menghasilkan produk sabun yang dapat digunakan dalam kehidupan sehari-hari di rumah tangga sehingga dapat memperkuat perekonomian keluarga di masa pandemi covid-19. Selanjutnya kegiatan ini berlangsung sangat baik, hal ini dapat dilihat dari respon dan antusias masyarakat yang sangat baik dalam kegiatan ini.

\section{UCAPAN TERIMA KASIH}

Ucapan Terima kasih kepada Rektor dan Ketua Lembaga Penelitian dan Pengabdian kepada Masyarakat Universitas Negeri Medan yang telah mendukung dan memberikan bantuan berupa sarana dan prasarana serta bantuan secara finansial melalui Dana PNBP dengan nomor kontrak
37/UN33.8/PM-PNBP/2020.

\section{REFERENSI}

Blue. F. 2014. Makalah Prakarya Budidaya Tanaman Obat. http://

blogsimpleuntukpelajar. blogspot.co.id. diakses tanggal 12 Desember 2015

Anonim.,Cara Membuat Sabun

Transparan, Tersedia dalam:abi-aksar. Carapembuatan-sabuntransparan.html/, diakses tanggal 4 April 2017.

Fatoni, R. dan Fatimah, S., 2017, Pengembangan Ekonomi Kreatif melalui Pembuatan Sabun Cair sebagai Upaya Pemberdayaan Anggota Aisiyah di Wilayah Solo Raya, The 6th University Research Colloquuium, Universitas Muhammadiyah Magelang.

Pasir, S., dan Hakim, M.S., 2014, Penyuluhan dan Praktik Pembuatan Sabun Cuci Piring Cair, Jurnal Inovasi dan Kewirausahaan, Vol. 3 no. 3 Hal 155-158.

Standar Nasional Indonesia., Standar Mutu Sabun Mandi, Dewan Standarisasi Nasional, Jakarta, 1994

Tito, R., Mendrova, R.P., dan Silaen, Y., Teknologi Tepat Guna Pembuatan Sabun Transparan, Makalah Teknik Kimia FT Universitas Riau, 2013. 